\title{
The DNA bill: Forensic science in the service of society
}

The new Criminal Law (Forensic Procedures) Amendment Bill of 2009, also called the 'DNA bill', passed its last Parliamentary hurdle on 22 August 2013. Now all that awaits is the passage through the National Council of Provinces and then Presidential approval, hopefully before the end of the year. President Zuma's signature will mean that South Africa will finally be in a position to generate a DNA database to fight crime.

But not everyone is happy. Worry about human rights was one of the factors that created the long 4-year delay. The original draft included a clause that allowed DNA samples to be stored for future reference, but Parliamentarians were concerned that storage of original samples could present opportunities for unscrupulous use of the samples to create a false crime scene. The final version does not allow for storage of original samples, but it does allow the DNA information itself to be stored. In fact, original samples are superfluous given our ability to store genomic information in searchable systems.

The database is science in the service of society. At the core is our ability to read the genetic code that shapes our bodies and defines us as individuals. The forensic application is not a complex one. It is simply the observation of a specific sequence of base pairs that allows us to unambiguously identify a single individual from the residual DNA found at a crime scene - the 'DNA fingerprint'. The DNA database will enable us to compare traces of DNA from the crime scene to individuals who already have a criminal record and whose genetic data are stored in the database. The technique does not allow the identification of individuals not on the database, but it can be used to find serial perpetrators and to exclude the innocent. The job requires the attention of a scientifically qualified technician who understands the basics of genetics, molecular biochemistry and the methodology of sample collection as well as analysis.

We are not going to get our skilled technicians out of thin air. We will need to train them, and we will need to teach them well. Leaving this instruction to the SAPS is probably an unwise decision as their in-house training is focused on preparing the students to process laboratory cases. Even if technicians never do research themselves, they need to understand the nature of science, how research is done, and - most important in my mind - the full implications of how the science is applied in the legal system. Not only must they understand the science, but they must be able to explain it to all those non-scientists in the legal system - the judges, the lawyers, the victims and the accused.

Unfortunately, non-scientists often misunderstand the use of science in the legal forum. There is actually a jargon term to describe this misunderstanding - the 'CSI effect', after the forensic science drama CSI: Crime Scene Investigation. Anyone who has a television set, goes to the movies or reads a good detective novel thinks they know more about forensic science in general and forensic anthropology in particular than many of the practitioners in the field. The CSI effect generates problems by creating a fallacy that forensic science can solve crime as quickly and definitively as it is done on television crime shows. Not only that, but it creates the impression that scientific data are absolutely infallible. The public is developing unrealistic expectations that forensic science can solve all questions and these misconceptions give no idea of the real costs of tests, the time involved and the level of uncertainty that is inherent in any form of scientific data.

Countering the CSI effect requires two things: forensic science workers who have a high quality university scientific education and therefore are real experts of the subject and know the limitations of their data; and the ability of these same workers to explain their activities and laboratory results to non-scientists in the public forum.

Specific programmes for teaching forensic science outside of the police services in South Africa are relatively new. The Universities of Cape Town, Pretoria and the Witwatersrand have offered Forensic Anthropology themes within their Anatomy courses at honours, master's and PhD levels for the last 10 years or so, and Stellenbosch University will be following suit shortly. The University of the Western Cape offers a master's degree in Forensic Odontology and the University of the Witwatersrand has a new honours course in Forensic Medicine and Pathology, separate from the clinical pathology stream. Honours programmes in Forensic Genetics are on offer at the University of Cape Town and the University of the Western Cape. The University of the Free State has just launched the first year of its undergraduate BSc in Forensic Science which will include a wide range of genetics, chemistry and general 'forensic science' as the course is rolled out over the next 2 years. No other courses are offered at undergraduate level and the only other broad-based programme is the MPhil in Biomedical Forensic Science launched in 2012 at the University of Cape Town.

The development of these programmes has been paralleled by the growth in forensic science research, especially in forensic anthropology. By my count we now have produced at least three PhDs and half a dozen MSc degrees in Forensic Anthropology and we currently have double that number of students working on their degrees. Projects include studies of decomposition, sex identification from bone, age changes in the skeleton, stature reconstruction, understanding bone trauma and facial reconstruction and imaging.

This development of new programmes and growth of research centres has been done independently at each institution, and we have not yet really considered where we are going in forensic science research and training on a national level. How will these students with high level research skills and expert knowledge slot into the current system of criminal investigation? How will research in these programmes be funded? Should we have a local forensic science journal for the publication of the output of our research? How can we make use of other initiatives like the African Network of Forensic Medicine launched in 2010 ?

Forensic science in South Africa will be in the full glare of publicity when the DNA bill takes effect and we need to realise that its impact will be far greater than just building a DNA database. Those of us teaching and doing forensic research in the university system are responsible for ensuring that our graduates meet the highest standard of practice as technicians and managers in police forensic laboratories and university research centres and as communicators to the public at large.

HOW TO CITE: Morris AG. The DNA bill: Forensic science in the service of society. S Afr J Sci. 2013;109(11/12), Art. \#a0043, 1 page. http://dx.doi.org/10.1590/sajs.2013/a0043 